Island Studies Journal, Vol. 5, No. 1, 2010, pp. 89-110

\title{
European Islands, Development and the Cohesion Policy: A Case Study of Kökar, Åland Islands
}

\section{Godfrey Baldacchino}

Canada Research Chair (Island Studies)

University of Prince Edward Island, Canada

Visiting Professor of Sociology, University of Malta, Malta

gbaldacchino@upei.ca

and

Christian Pleijel

Archipelago Developer of the Aland Government

Vice-Chair, Municipal Executive Board, Kökar Municipality, Aland Islands, Finland

christian@pleijel.net

\begin{abstract}
A European Union initiative is seeking ways of determining the development potential of Europe's lagging regions, which include various islands. On the basis of the policy review, methodology and data collected by the ongoing EUROISLANDS project, this paper present Kökar (population: 262), the easternmost municipality of the Åland Islands, as a prototype archipelago that is seriously challenged by its size and multiple peripherality. It reviews the state of its social and transportation infrastructure, and of its human and financial capital. While the situation is serious, there are opportunities for branding, for developing associated economic activity, as well for appealing to a new wave of residents.
\end{abstract}

Keywords: EUROISLANDS, Åland Islands, attractiveness, European Union, Finland, islands, Kökar, peripherality, Sweden

(C) 2010 - Institute of Island Studies, University of Prince Edward Island, Canada

\section{Introduction}

Islands, especially smaller ones, are often considered to be disadvantaged regions which face specific challenges. These challenges are related to such factors as: peripheral location and relative isolation; a high dependency on external inputs and few (often seasonal) activities or export products; a small domestic market; low administrative autonomy and/or weak administrative capacity; demographic imbalances; insufficient public infrastructures and services; acute pressures on the use of land and natural resources; and an environment sensitive to natural hazards (e.g. Srinivasan, 1986). Where such challenges are recognized and acknowledged, a national and/or regional transfer of funds has tended to follow. The seven outermost, so-called "ultra peripheral regions" of the EU (of which all but one are islands) have led the way here ${ }^{1}$ : they have been the subject of distinct legal arrangements,

${ }^{1}$ These are: the Azores and Madeira (Portugal); the four French overseas departments of French Guiana, Guadeloupe, Martinique and Reunion; and the Canaries (Spain). 
both as regards national law (autonomy status; customs arrangements; tax breaks) as well as EU law (as with the provisions adopted in the Treaties establishing the Community, notably Maastricht, Amsterdam, and now Lisbon) (CPMR, 2002, passim; Moncada et al., 2010).

Institutionalizing problem status, however, has its complications. Fiscal transfers easily become, in themselves, an additional form of dependency: for these islands, and their residents, they would in effect be "killed by kindness" (Hintjens, 1991: 51). Such a measure of continuous and chronic fiscal intervention is, therefore, perhaps not ideal as well as not necessarily sustainable; can it perhaps be (even if partially) replaced by strategic initiatives that speak to the assets, resources, entrepreneurship and opportunities of islands and islanders? After all, the constraints of small size and geographical separateness are often presumed to render islands particularly "vulnerable" (e.g. Briguglio, 1995); but such a categoric declaration fails to acknowledge that there are advantages as well as disadvantages associated with smallness and isolation (e.g. Bertram \& Poirine, 2007).

ESPON - the European Observation Network for Territorial Development and Cohesion was adopted by the European Commission in 2007. The ESPON mission is to:

"Support policy development in relation to the aim of territorial cohesion and a harmonious development of the European territory by: (1) providing comparable information, evidence, analysis and scenarios on territorial dynamics; and (2) revealing territorial capital and potentials for development of regions and larger territories contributing to European competitiveness, territorial cooperation and a sustainable and balanced development" (ESPON, 2010).

One particular, and current, ESPON project seeks to deliver an appropriate reference work as well as a set of policy recommendations and strategic guidance to foster the sustainable development of European islands. This is to be undertaken within the framework of the European Union (EU) Single Market, ensuring equal terms and opportunities with other, less handicapped regions. Such targeted analysis provides an opportunity to raise awareness at European level about 'insularity' - and its slate of associated challenges - as an issue that needs particular consideration and consensus building, taking into account the structural problems and the unequal opportunities within the European integration process. The study also allows for an elaboration of policy options that are coherent with broader EU policies and that encourage the endogenous development of the European Islands. Moreover, the study results can be used to disseminate policy options, raise public awareness and set the basis for discussion in the ongoing process of the EU's Territorial Agenda and the future deployment of its Structure Funds. The project - titled EUROISLANDS: the Development of the Islands; European Islands and Cohesion Policy, and running over 2009-2010 - has the Ministry of Economy \& Finance, Greece, as its lead stakeholder; and the Research Unit, University of the Aegean, Greece, as its main research partner (EUROISLANDS, 2010) ${ }^{2}$.

\footnotetext{
${ }^{2}$ The two other research project partners are: the Centre for Regional and Tourism Research, Bornholm, Denmark (www.crt.dk); and the University of Malta, Malta (www.um.edu.mt). The project's interim report is available at: www.commissiondesiles.org/pub/news/75 interim_report 010310.pdf
} 
As an integral part of this project, nine case studies were carried out to determine and classify the attractiveness factors of islands; within these studies, various questionnaires were constructed to investigate and record the opinions and attitudes of European stakeholders, local (or municipal) political representatives, island businesspersons and island residents regarding the factors that make islands more or less attractive for taking up local residence and/or for setting up local business ventures. This article is based on one of these nine case studies: that of Kökar, within the Åland Islands ${ }^{3}$.

\section{The Åland Archipelago}

"The archipelago is a world of contradictions: it is calm and wild, large and little, rich and poor, all at the same time, and this has had an effect on the traditions and the lifestyle of people living on the islands" (Kökar Culture, 2009).

The Åland archipelago is a home-ruled, demilitarized and Swedish-speaking jurisdiction located in the northern Baltic Sea, enjoying political autonomy within the realm of the state of Finland, thanks to an international treaty brokered by the League of Nations in 1920. This autonomous status has allowed Åland to ensure that its Swedish language and culture remain privileged. Åland had its own Annex to Finland's Treaty of Accession to the European Union in 1995. In particular, this annex endorses Åland's status as a duty free zone within the EU. Åland received its own flag in 1954, its own stamps in 1984, and now has its own high-level internet domain (.ax). Since 1970, Åland has its own representation on the Nordic Council. Åland also obtains funding for its own EU programmes: that applies to the Objective 2 and Objective 3 Programmes, the Rural Development Programme and the Structural Programme for the Fisheries Industry (Lindström, 1997, 2000, 2009).

Åland consists of a main island surrounded by some 6,500 smaller islands, of which around 60 are inhabited. The population is around 27,000: some $40 \%$ of this lives in the capital city, Mariehamn; and a further $50 \%$ live in the countryside on the main island, which is within commuting distance by car from Mariehamn.

Alland's GPD per capita ranks amongst the highest in the Finnish regions, and surpasses the Finnish average. The Alland national income is about $25 \%$ higher than the Finnish average. Åland also has the highest GDP per capita of the Nordic countries, measured in purchasing power parity (Journal of NordRegio, 2006).

Åland has sixteen municipalities. Six of these - Brändö, Föglö, Kökar, Kumlinge, Sottunga and Vårdö - are situated in the archipelago region and are not connected to the main island by road or bridge. These six municipalities now contain less than $10 \%$ of the Alland population. They depend on their links with the main island and the capital city on a network of car ferries (Alandstrafiken, 2010; see Figure 1).

\footnotetext{
${ }^{3}$ The others being Cyprus, Kalymnos-Lipsi, Lipari, Mallorca, Malta, Saaremaa, Samsø and Sardinia.
} 
Figure 1: Reproduced from: ÅSUB (2009: 12-13). Kökar municipality circled in bottom right. (C) Maridea Reklambyra. Reproduced with permission.

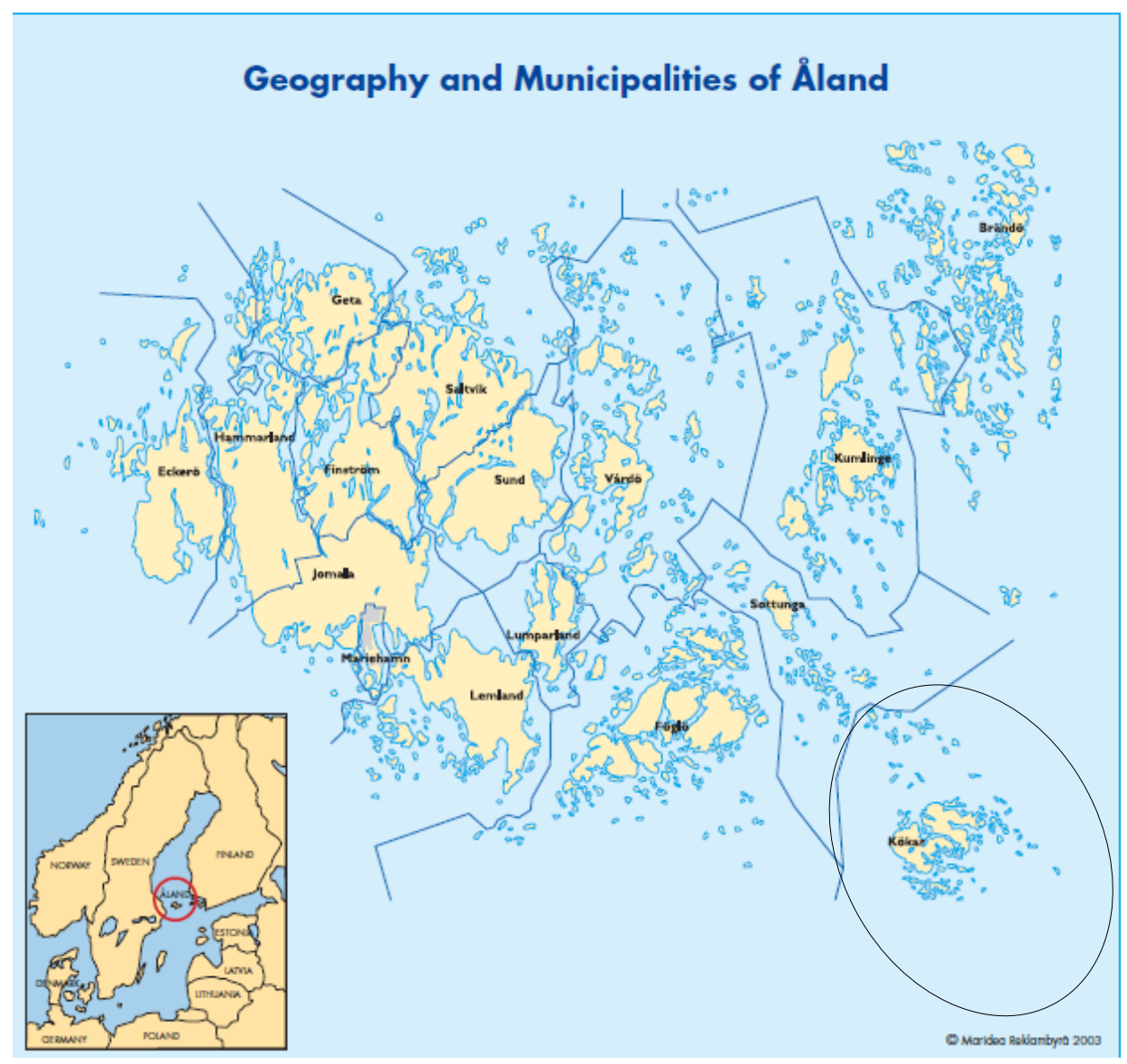

Out of the 10 'mainland' municipalities, only the one furthest from Mariehamn (Geta) has registered a population decline since 1980; however, of the six 'archipelago' municipalities, all six have registered a dramatic decline from 1950-1980, and all six except one have seen a more moderate slide (but still a decline) since 1980. The proportion of city dwellers has actually fallen slightly from $41.9 \%$ in 1980 to $40.1 \% 2007$. The proportion of archipelago dwellers has fallen from $10.8 \%$ in 1980 to $8.6 \%$ in 2006 , and $8.3 \%$ in 2007 . It is the exurb on the main island that has seen a population increase: from $47.3 \%$ in 1980 to $51.6 \%$ in 2007 . Jomala, just outside Mariehamn, is showing the fastest growth of all. Most of these demographic changes are however not dramatic, and an equitable gender balance has been maintained throughout the territory. Only one out of the six archipelago municipalities (Vårdö) has actually registered consistent population increases throughout this time: probably thanks to a 'fixed link' to mainland Âland built in the 1980 s, along with a 5-8 minute cable ferry crossing via Prästö, operating 24 hours a day. With just 115 residents, Sottunga must be seriously threatened by the sustainability of its settlement. Meanwhile, the only significant population slide is at Kumlinge: it lost $10 \%$ of its population from 1980 to 2000, and has lost another 11\% between 2000 and 2006. Nevertheless, the archipelago population has been halved since 1950. For population trends in the six archipelago municipalities (1950-2007), see Figure 2. 
Figure 2: Population Changes in the Six Archipelago Muncipalities of Åland: 1950-2009.

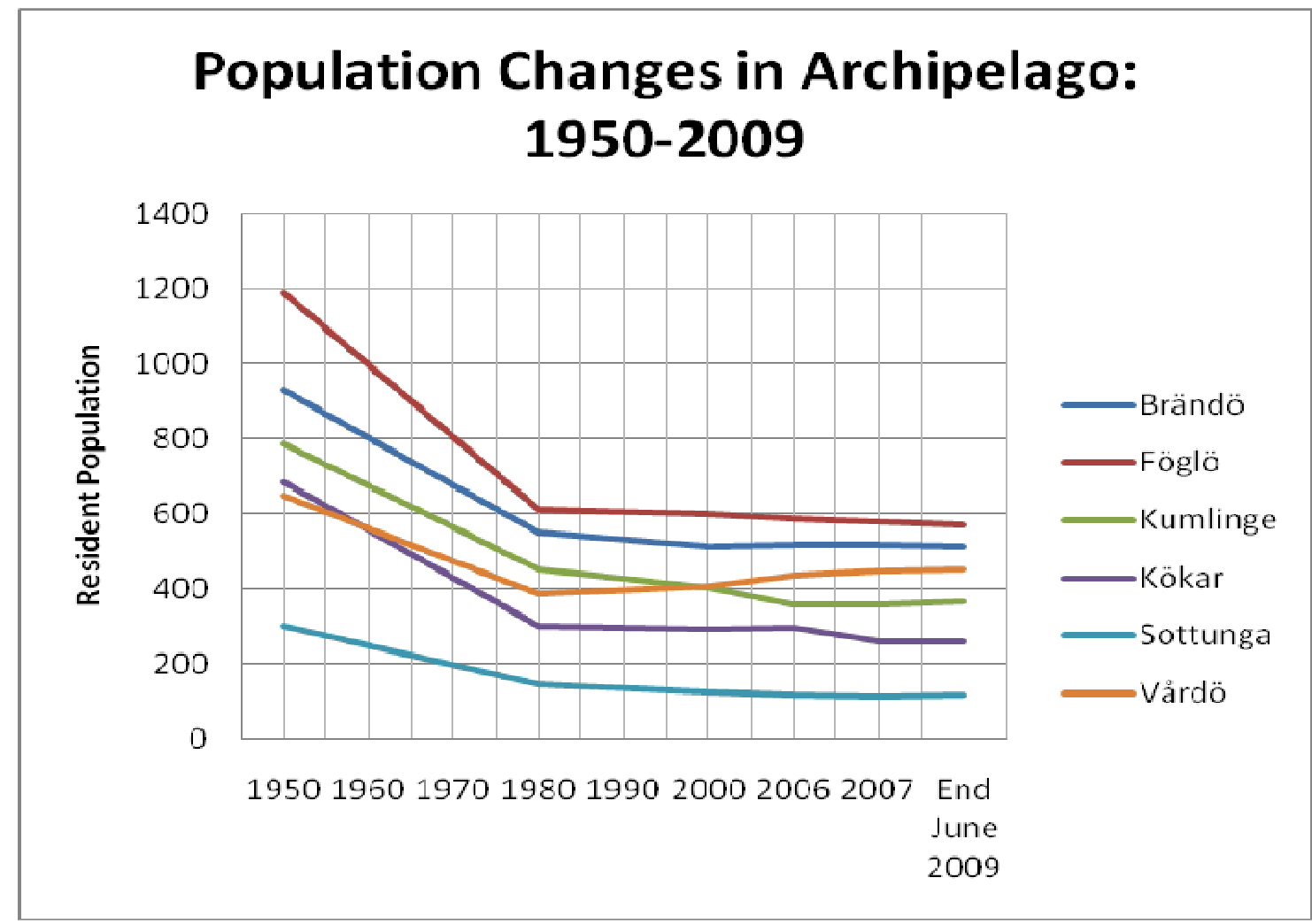

The Åland archipelago is part of a cross-national Baltic Sea region that stretches from Stockholm to Åbo/Turku and which has had a particular economic history. It also boasts the region with the world's largest density of islands (Depraetere, 2007). While the shipping industry cluster - with its duty free exemptions - remains important for Åland, the territory has seen its major economic efforts shift from resource-based activity (such as farming, cattle raising and milking, herring fishing, forestry, hunting) to service sector activities like tourism, construction, hospitality, bouquet manufacturing, yacht and pleasure craft maintenance (e.g. Skårgårdscentrum Korpoström, 2006). Given the increasing attraction of such islanded places for place-based tourism, summer residences and pleasure travel, we should not be surprised to find that this sprawling Suedo-Finnish archipelago is now the target of some 3 million visitors annually. Some interesting recent initiatives geared to promote Åland as a more attractive region for visitors include: (1) a branding exercise to promote local food and craft products (Skärgårdssmak, 2009); as well as (2) the 'archipedalo': a trans-national project to create a biking trail between Åland and South-West Finland (Archipedalo, 2009).

\section{Introducing Kökar}

"Reached by ferry from Korpo (74km/46 miles south-west of Turku) or Långnäs (28km/ 17 miles east of Mariehamn) is the sailing enthusiasts' paradise of Kökar (population: 300; Sandvik and Hellsö boating harbours), far out in the skerries. It has a fine church of grey stone, built on the ruins of a Franciscan friary. Hotel, restaurant, camping site" (Planetware, 2009). 
"On a sunny summer's day, this island group is three-coloured: blue skies and waters, nearly black rock, lush green juniper and grass. A short ferry ride from Korpo or main Åland takes you there, and today you can find good accommodation - but be sure to book in advance if you plan to go in July or August!'(Per, 2008).

Table 1: Åland Population by Municipality: various end-of-year figures and estimates for 30 June 2009. (The Six 'Archipelago' municipalities are highlighted with a light blue background). (Sources: ÅSUB (2007; 2009). June 2009 estimates from: www.vrk.fi/vrk/files.nsf/files/AE1290D892E86719C22575EB002B065C/\$file/090630.html)

\begin{tabular}{|c|c|c|c|c|c|c|}
\hline & 1950 & 1980 & 2000 & 2006 & 2007 & End June 2009 \\
\hline Brändö & 927 & 550 & 514 & 520 & 518 & 515 \\
\hline Eckerö & 942 & 685 & 830 & 929 & 921 & 943 \\
\hline Finström & 2,089 & 2,052 & 2,299 & 2,464 & 2,483 & 2,496 \\
\hline Föglö & 1,188 & 608 & 595 & 583 & 576 & 568 \\
\hline Geta & 775 & 471 & 478 & 448 & 456 & 458 \\
\hline Hammarland & 1,454 & 1,196 & 1,351 & 1,423 & 1,440 & 1,457 \\
\hline Jomala & 3,413 & 2,615 & 3,328 & 3,664 & 3,917 & 3,959 \\
\hline Kumlinge & 788 & 454 & 405 & 359 & 360 & 367 \\
\hline Kökar & 683 & 304 & 296 & 298 & 262 & 263 \\
\hline Lemland & 1,342 & 954 & 1,585 & 1,731 & 1,783 & 1,782 \\
\hline Lumparland & 448 & 302 & 377 & 387 & 387 & 383 \\
\hline Saltvik & 2,041 & 1,564 & 1,679 & 1,706 & 1,753 & 1,756 \\
\hline Sottunga & 299 & 149 & 129 & 120 & 115 & 118 \\
\hline Sund & 1,382 & 939 & 1,013 & 1,033 & 1,031 & 1,035 \\
\hline Vårdö & 646 & 387 & 409 & 434 & 449 & 453 \\
\hline Mariehamn & 3,273 & 9,553 & 10,488 & 10,824 & 11,005 & 11,155 \\
\hline Rural Districts & 18,417 & 10,778 & 12,940 & 13,785 & 14,171 & 14,269 \\
\hline Archipelago & 4,531 & 2,452 & 2,348 & 2,314 & 2,280 & 2,284 \\
\hline Åland (total) & 21,690 & 22,783 & 25,776 & 26,923 & 27,456 & 27,708 \\
\hline Females & & 11,509 & 13,076 & 13,571 & 13,815 & \\
\hline Males & & 11,274 & 12,700 & 13,352 & 13,641 & \\
\hline
\end{tabular}


Kökar (land area: $58 \mathrm{~km}^{2}$ ) is Åland's second smallest municipality by population size, and the one furthest away from the jurisdictional hub of Mariehamn (see Figure 1). Its landscape contrasts sharply from that of mainland Åland, since it is dominated by naked grey bedrock of gneiss, covered in small brushwood, with alder, birch and juniper trees, and surrounded by the open sea with thousands of treeless islands and skerries. The first inhabitants were probably sealers who settled at the Otterböte site, around $100 \mathrm{BC}$. During the 15th century, a Franciscan monastery was founded on Hamnö. This place became a spiritual and cultural centre of the entire archipelago (Guild Travel, 2010; Kökar Commune, 2009).

In the past, Kökar's economy was largely based on fishing and hunting. Most important of all was the seasonal fishing for Baltic herring that took place from the outmost skerries of Ören and Mörskär. Today, the Kökar economy is dominated by tourism, transport and tourism-related industries, and employment with the municipality, combined with some farming (Kokar Culture, 2009).

Kökar's total population (as at the end of 2007) was 262, or just about 140 households: what is left today in the wake of a fairly erratic population decline. This trend has not been consistent over the various decades: a major loss of over 200 residents occurred in the 19601970 period; but there was a stable population count between 1990 and 2000. The population reached its maximum around 1920, when some 1,000 people lived in five villages. By 1950, the population had been almost halved, but was still more than twice the current level (see Table 2).

Table 2: - Change of Kökar Population: 1950-2007

\begin{tabular}{|c|c|c|c|c|c|c|c|c|}
\hline Year & 1950 & 1960 & 1970 & 1980 & 1990 & 2000 & 2007 & $\begin{array}{c}\text { End } \\
2007\end{array}$ \\
\hline Population & 683 & 561 & 369 & 304 & 296 & 296 & 284 & 262 \\
\hline
\end{tabular}

The distribution of the population of Kökar is decidedly older on average - just under a quarter of the Kökar population is 65 years of age or older (compared to just over a sixth for Åland as a whole) - (see Table 3$)$.

Table 3: - Comparing Population Distributions in Åland and Kökar (end 2007)

\begin{tabular}{|c|c|r|c|r|}
\hline $\begin{array}{c}\text { Age } \\
\text { Group }\end{array}$ & $\begin{array}{c}\text { Kökar } \\
\text { (Numbers) }\end{array}$ & $\begin{array}{c}\text { Kökar } \\
\text { (by \%) }\end{array}$ & $\begin{array}{c}\text { Åland } \\
\text { (Numbers) }\end{array}$ & \multicolumn{1}{c|}{$\begin{array}{c}\text { Aland } \\
\text { (by \%) }\end{array}$} \\
\hline $0-14$ & 39 & 14.9 & 4,625 & 16.8 \\
\hline $15-64$ & 158 & 60.3 & 18,052 & 65.7 \\
\hline $65+$ & 65 & 24.8 & 4,779 & 17.4 \\
\hline Total & 262 & 100.00 & 27,456 & 100.00 \\
\hline
\end{tabular}

These demographic characteristics are typical of very small and remote, mainly island, populations facing population decline. Research suggests that opportunities for employment and self-employment, along with the provision of basic and affordable infrastructural 
services - not just water and electricity, but health care, basic education, inexpensive and efficient transportation to/from the mainland, broadband ... - will be crucial to stem population decline, or even contribute to population increase (e.g. Barthon, 2007; Royle, 2007). Kökar may be fortunate than most in still having a significant population of children under the age of 15, a proportion only slightly lower than that for Åland as a whole. This is further borne out by an analysis of the demographic changes on Kökar over a 10-year span (1997-2006). While deaths have exceeded births, the shortfall has not been that dramatic; and migration to the municipality has been almost as large as out-migration (see Table 4).

Table 4: - Net Population Changes on Kökar: 1997-2006

\begin{tabular}{|c|c|c|c|c|c|c|}
\hline Births & Deaths & $\begin{array}{c}\text { In- } \\
\text { Migration }\end{array}$ & $\begin{array}{c}\text { Out- } \\
\text { Migration }\end{array}$ & $\begin{array}{c}\text { Change in } \\
\text { Population }\end{array}$ & Correction & $\begin{array}{c}\text { Actual } \\
\text { Change }\end{array}$ \\
\hline 31 & 40 & 165 & 176 & -20 & -2 & -22 \\
\hline
\end{tabular}

The reasons for the population decline on Kökar however do not appear to be primarily related to economic issues, even though the perception of deprivation can be driven by relative (rather than absolute) assessments. Unemployment figures can be useful indirect indicators of opportunities for employment and self-employment. Even after the latest global financial crisis, unemployment levels on Kökar have only budged slightly, and only to reach the same levels as 2007: from a mean of 2.4\% in August 2008 to 3.2\% in August 2009. (Of course, with such a small labour force, this actually means that the number of registered unemployed on Kökar has changed from 4 to 5 persons!) These are percentage figures that most countries would be very envious of - though they are, and have been consistently, still slightly higher than those for Åland as a whole (see Table 5).

Table 5: - Unemployment rates for both Kökar and Åland as a Whole (2003-2009)

\begin{tabular}{|l|c|c|c|c|c|c|c|c|}
\hline Year & $\mathbf{2 0 0 3}$ & $\mathbf{2 0 0 4}$ & $\mathbf{2 0 0 5}$ & $\mathbf{2 0 0 6}$ & $\mathbf{2 0 0 7}$ & $\mathbf{2 0 0 8}$ & Aug-08 & Aug-09 \\
\hline Kökar & 3.1 & 4.0 & 3.1 & 2.7 & 3.1 & 2.3 & 2.4 & 3.2 \\
\hline Åland & 1.9 & 2.6 & 2.3 & 2.2 & 2.1 & 2.0 & 2.0 & 2.9 \\
\hline
\end{tabular}

Some (again indirect) indication of economic activity on the Åland archipelago can be gleaned from data pertaining to the use of ferries. Larger volume of passengers and vehicles - in spite of overall population decline - may be indicative of greater volume of visitors, or of residents being able to afford, or needing to depend on, more trips to/from Mariehamn (see Table 6).

Table 6: - Number of Passengers \& Vehicles on Archipelago Ferries (1990-2007)

\begin{tabular}{|l|r|r|r|r|}
\hline Year & $\mathbf{1 9 9 0}$ & $\mathbf{2 0 0 0}$ & \multicolumn{1}{c|}{$\mathbf{2 0 0 6}$} & \multicolumn{1}{c|}{$\mathbf{2 0 0 7}$} \\
\hline Passengers & 929,659 & $1,048,933$ & $1,057,516$ & $1,155,113$ \\
\hline Vehicles & 441,376 & 525,070 & 554,681 & 612,450 \\
\hline
\end{tabular}


The introduction of regular, all-year-round ferry services (capable of vehicle transportation) in the early 1970s - and offered free of charge to residents of the archipelago - has coincided with a significant 'brake' in the rate of population out-migration from the archipelago.

\section{Responses to ESPON Survey Questionnaires}

Two ESPON survey questionnaires were administered to Kökar respondents during September and October 2009: one for local residents and the other for local business operators and/or owners. In all, 13 business representatives (4 females and 9 males) and 17 residents ( 9 females and 8 males) responded: an excellent response rate of over $11 \%$ of the total population of Kökar.

In response to a battery of 28 'quality of life' indicators, the business respondents were very strongly appreciative of only one: that of "the cost of air/sea travel to the mainland". Commercial air services to Kökar are not available; but the ferry service is free to the residents ${ }^{4}$. The only other two variables that secured a fairly strong positive response were about the regularity of the water supply and the general feeling of safety and security on Kökar. Meanwhile, there was only one variable on which Kökar business respondents were in strong disagreement: that "there were sufficient opportunities for training of employees on their municipality". The overall tone, however, is decidedly negative: business respondents scored mean negative scores on 19 out of the 28 variables listed. Nevertheless, and in spite of the overall negative assessment, the business respondents feel that they have considerable mutual trust and that their outlook for the future of their business remains mildly optimistic. Business respondents also reported that they do not have broadband access to the internet on Kökar (see Table 7).

In the opinion of the sampled businesspersons, the most important factors that make the island attractive for setting up of local economic activities are: the beauty of the natural surroundings, which in turn lend themselves to various kind of mass and niche tourism; the transportation services available; the entrepreneurial drive; the connection that such activities have to the island's core features and characteristics; in-migration; start-up help and support; networking; sound planning; and schools.

In contrast, the conditions which could lead these same businesspersons to close down or terminate their business activity include: lack of tourists; decline of the local population; higher taxes; changes in ferry schedule; insufficient business revenue and their illhealth/sickness or that of close family members.

\footnotetext{
${ }^{4}$ Business Respondents were asked to choose one out of six options for each of 28 'quality of life' statements: If they agreed totally, their reply was assigned +2 points; if they agreed, +1 point; if they disagreed, -1 point; and if they disagreed totally, -2 points. No score was assigned to "neither agree nor disagree", don't knows and non-responses. The same approach was used with the Resident Respondents, but on a slightly different and shorter battery of 25 'quality of life' statements.
} 
Table 7: Business Responses to a Battery of 28 Quality of Life Indicators $(\mathrm{N}=13)$. Positive and very positive scores have a blue background in the final column; negative and very negative scores have a red background in the same column.

\begin{tabular}{|c|c|c|c|c|c|c|c|c|}
\hline Business Responses $(\mathrm{N}=13)$ & 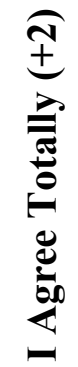 & 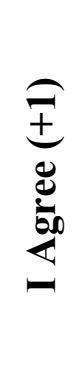 & 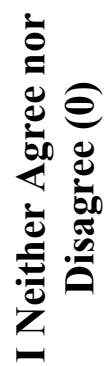 & 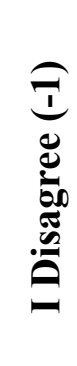 & 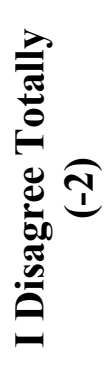 & 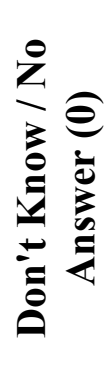 & $\stackrel{\pi}{\mathscr{\sigma}}$ & 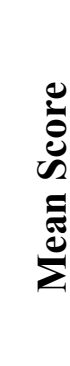 \\
\hline $\begin{array}{l}\text { 1.Frequency of scheduled } \\
\text { trips (by ferry, ship, plane) is } \\
\text { adequate }\end{array}$ & 2 & 5 & 1 & 2 & 2 & 1 & 13 & 3 \\
\hline $\begin{array}{l}\text { 2. The cost of air or sea travel } \\
\text { to mainland is praiseworthy }\end{array}$ & 6 & 5 & 2 & 0 & 0 & 0 & 13 & 17 \\
\hline $\begin{array}{l}\text { 3. Cost of transport of goods } \\
\text { from/to island is praiseworthy }\end{array}$ & 1 & 5 & 1 & 0 & 6 & 0 & 13 & -5 \\
\hline $\begin{array}{l}\text { 4. Quality of transport } \\
\text { services to mainland is } \\
\text { satisfactory }\end{array}$ & 1 & 7 & 2 & 2 & 1 & 0 & 13 & -5 \\
\hline $\begin{array}{l}\text { 5. The broadband connection } \\
\text { is satisfactory }\end{array}$ & 2 & 1 & 3 & 2 & 4 & 1 & 13 & -5 \\
\hline $\begin{array}{l}\text { 6. The regularity of energy } \\
\text { supply is sufficient }\end{array}$ & 1 & 7 & 1 & 2 & 1 & 1 & 13 & 5 \\
\hline $\begin{array}{l}\text { 7. The regularity of water } \\
\text { supply is sufficient }\end{array}$ & 5 & 6 & 1 & 0 & 1 & 0 & 13 & 14 \\
\hline $\begin{array}{l}\text { 8. Waste water collection \& } \\
\text { treatment system is adequate }\end{array}$ & 0 & 5 & 1 & 5 & 2 & 0 & 13 & -4 \\
\hline $\begin{array}{l}\text { 9. The quality of local public } \\
\text { transportation network covers } \\
\text { the local needs }\end{array}$ & 2 & 2 & 3 & 4 & 2 & 0 & 13 & -2 \\
\hline $\begin{array}{l}\text { 10. There is sufficient and } \\
\text { available trained/qualified } \\
\text { human capital in the area/ } \\
\text { island }\end{array}$ & 1 & 2 & 2 & 3 & 4 & 1 & 13 & -7 \\
\hline $\begin{array}{l}\text { 11. There are sufficient } \\
\text { opportunities for training of } \\
\text { the employees in the } \\
\text { area/island }\end{array}$ & 1 & 0 & 1 & 4 & 7 & 0 & 13 & -16 \\
\hline $\begin{array}{l}\text { 12. The land and construction } \\
\text { cost of commercial property } \\
\text { is praiseworthy }\end{array}$ & 1 & 2 & 2 & 4 & 3 & 1 & 13 & -6 \\
\hline
\end{tabular}




\begin{tabular}{|c|c|c|c|c|c|c|c|c|}
\hline $\begin{array}{l}\text { 13. The cost of living is } \\
\text { satisfactory }\end{array}$ & 0 & 3 & 1 & 6 & 3 & 0 & 13 & -9 \\
\hline $\begin{array}{l}\text { 14. The local Public } \\
\text { Administration is effective }\end{array}$ & 1 & 4 & 2 & 3 & 3 & 0 & 13 & -3 \\
\hline $\begin{array}{l}\text { 15. The labour cost is } \\
\text { satisfactory }\end{array}$ & 1 & 4 & 3 & 2 & 2 & 1 & 13 & 0 \\
\hline $\begin{array}{l}\text { 16. The business support } \\
\text { agencies (such as business } \\
\text { development corporations) } \\
\text { are adequate }\end{array}$ & 0 & 4 & 2 & 2 & 5 & 0 & 13 & -8 \\
\hline $\begin{array}{l}\text { 17. There is sufficient support } \\
\text { by other businesses (goods } \\
\text { and services of local market) }\end{array}$ & 0 & 4 & 2 & 2 & 5 & 0 & 13 & -8 \\
\hline $\begin{array}{l}\text { 18. The Economic incentives } \\
\text { to businesses (subsidies, tax } \\
\text { incentives) are sufficient }\end{array}$ & 0 & 3 & 1 & 4 & 4 & 1 & 13 & -9 \\
\hline $\begin{array}{l}\text { 19. The possibility to support } \\
\text { innovations in the production } \\
\text { process is sufficient }\end{array}$ & 0 & 2 & 4 & 4 & 2 & 1 & 13 & -6 \\
\hline $\begin{array}{l}\text { 20. There is the possibility to } \\
\text { develop cooperation with } \\
\text { other businesses for } \\
\text { information and know-how } \\
\text { exchange }\end{array}$ & 1 & 7 & 2 & 0 & 3 & 0 & 13 & 3 \\
\hline $\begin{array}{l}\text { 21. Local authorities show } \\
\text { sufficient competence to } \\
\text { solve problems }\end{array}$ & 1 & 4 & 1 & 2 & 5 & 0 & 13 & -6 \\
\hline $\begin{array}{l}\text { 22. Local authorities have an } \\
\text { adequate development vision } \\
\text { (strategy, plan, activation) }\end{array}$ & 1 & 2 & 2 & 3 & 5 & 0 & 13 & -9 \\
\hline $\begin{array}{l}23 \text {. The degree of } \\
\text { stakeholders' involvement in } \\
\text { the decision making process } \\
\text { is sufficient }\end{array}$ & 1 & 3 & 4 & 2 & 2 & 1 & 13 & -1 \\
\hline $\begin{array}{l}\text { 24. I generally feel security } \\
\text { (from criminal activities) }\end{array}$ & 5 & 6 & 0 & 2 & 0 & 0 & 13 & 14 \\
\hline $\begin{array}{l}\text { 25. My trust in the local } \\
\text { municipality is high }\end{array}$ & 1 & 3 & 4 & 2 & 3 & 0 & 13 & -3 \\
\hline $\begin{array}{l}\text { 26. Generally the locals are } \\
\text { trustworthy }\end{array}$ & 2 & 7 & 2 & 1 & 1 & 0 & 13 & 8 \\
\hline $\begin{array}{l}\text { 27. My interest for the local } \\
\text { politics is high }\end{array}$ & 1 & 2 & 5 & 2 & 3 & 0 & 13 & -4 \\
\hline $\begin{array}{l}28 . \text { Perspective of my } \\
\text { business on the island is } \\
\text { positive }\end{array}$ & 2 & 5 & 4 & 1 & 1 & 0 & 13 & 6 \\
\hline
\end{tabular}


When asked to volunteer additional information, these business respondents suggested: more EU funding to support small business and facilitate investment on Kökar; an airfield and air services for improved access; faster broadband availability; the repatriation of the powers of taxation by Åland from Helsinki; more attention to pollution and eutrophication in the Baltic sea; and, of course, that a population increase would be more than welcome.

None of the commercial operations of these business respondents had a franchise; and only one was a subsidiary of a larger company (with operations in other parts of Åland). Many of these businesses have been in operation for many years. This suggests small family-owned operations servicing local markets and clients, including visitors ${ }^{5}$.

Turning now to the sampled Kökar residents, they are significantly much more optimistic than the sampled business persons: their scores on 17 out of 25 'quality of life' variables are positive; on 11 of these, emphatically so. The sampled residents share with the business respondents an appreciation for the low cost (actually no cost) of ferry travel to the mainland; and an appreciation for safety and security. But they then go along to express generally positive opinions about: the quality of transport services to the mainland, the regularity of energy and water supplies, the short daily commutes, low noises, clean air, the quality of the built environment, the degree of civic involvement in decision making, and trust in both fellow residents and local authorities. They leave the highest appreciation of all to the beauty of their natural surroundings. Their lowest score by far is for the declaration that "there are sufficient job opportunities" on Kökar, followed closely by a low score on the statements that "the cost of living is satisfactory" and "there are sufficient opportunities for training" (see Table 8).

Clearly, the absence of training opportunities for employees on Kökar is seen as a most serious concern by both resident and business respondents: only 3 out of 30 respondents believe that training opportunities for employees on Kökar are "satisfactory".

The resident respondents were also asked to indicate since when they have lived permanently in Kökar. Interestingly, only 5 out of 17 resident respondents have lived on Kökar for all their life. This suggests a fair degree of rotation of residents. The remaining 12 have moved to Kökar from either 'metropolitan Åland' (especially Mariehamn, but also Finström), the rest of Finland (e.g. Åbo/Turku) or parts of Sweden. Those coming to live on Kökar are presumably doing so on the basis of a well-thought out decision: they are trading the little luxuries of metropolitan life for a peaceful, safe and beautiful - but also more expensive ${ }^{6}$, more isolated and logistically much more challenging - haven. The residents now have "quality" health services on Kökar - as one respondent, a professional nurse, suggested; and education can be pursued in Kökar for the first nine years of compulsory schooling (ages 716 ), and so there are no "early school leavers".

\footnotetext{
${ }^{5}$ For the sake of perspective, Åland as a whole had only 65 private companies employing more than 20 workers each in 2008.

${ }^{6}$ For example, if an electrician is needed to do a job that takes 2 hours, s/he will also charge for the 5-6 hours of travelling time to/from Kökar, inclusive of fuel. Food is some $15-20 \%$ higher than in Mariehamn; petrol was 40\% more expensive on Kökar than in Mariehamn in summer 2009.
} 
Table 8: Resident Responses to a Battery of 25 Quality of Life Indicators $(\mathrm{N}=17)$ Positive and very positive scores have a blue background in the final column; negative and very negative scores have a red background in the same column.

\begin{tabular}{|c|c|c|c|c|c|c|c|c|}
\hline $\begin{array}{l}\text { Resident Respondents } \\
\qquad(\mathbf{N}=17)\end{array}$ & 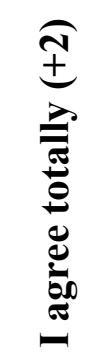 & 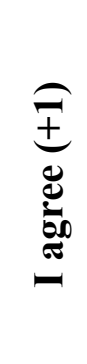 & 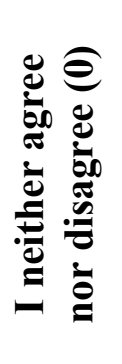 & 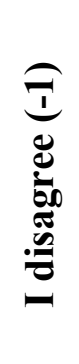 & 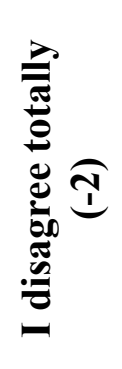 & 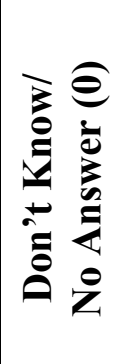 & 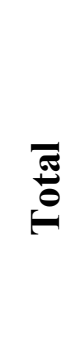 & 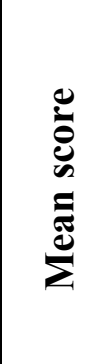 \\
\hline $\begin{array}{l}\text { 1. Frequency of scheduled } \\
\text { trips (by ferry, ship, plane) } \\
\text { is adequate }\end{array}$ & 0 & 13 & 1 & 2 & 1 & 0 & 17 & 9 \\
\hline $\begin{array}{l}\text { 2. The cost of air or sea } \\
\text { travel to mainland is } \\
\text { praiseworthy }\end{array}$ & 9 & 4 & 1 & 2 & 0 & 1 & 17 & 20 \\
\hline $\begin{array}{l}\text { 3. Quality of transport } \\
\text { services to mainland is } \\
\text { satisfactory }\end{array}$ & 6 & 6 & 1 & 3 & 1 & 0 & 17 & 13 \\
\hline $\begin{array}{l}\text { 4. The broadband } \\
\text { connection is satisfactory }\end{array}$ & 0 & 3 & 2 & 9 & 1 & 2 & 17 & -8 \\
\hline $\begin{array}{l}\text { 5. The regularity of energy } \\
\text { supply is sufficient }\end{array}$ & 6 & 5 & 1 & 4 & 1 & 0 & 17 & 11 \\
\hline $\begin{array}{l}\text { 6. The regularity of water } \\
\text { supply is sufficient }\end{array}$ & 10 & 5 & 1 & 0 & 0 & 1 & 17 & 25 \\
\hline $\begin{array}{l}\text { 7. Waste water collection \& } \\
\text { treatment system is adequate }\end{array}$ & 3 & 5 & 3 & 3 & 3 & 0 & 17 & 2 \\
\hline $\begin{array}{lr}\text { 8. Quality of local public } \\
\text { transportation } & \text { network } \\
\text { covers local needs } & \end{array}$ & 3 & 5 & 4 & 4 & 1 & 0 & 17 & 5 \\
\hline $\begin{array}{l}\text { 9. There are sufficient job } \\
\text { opportunities }\end{array}$ & 0 & 3 & 1 & 7 & 6 & 0 & 17 & -16 \\
\hline $\begin{array}{l}\text { 10. There are sufficient } \\
\text { opportunities for training }\end{array}$ & 0 & 2 & 6 & 4 & 4 & 1 & 17 & -10 \\
\hline $\begin{array}{l}\text { 11. There are adequate } \\
\text { opportunities to attend } \\
\text { cultural events }\end{array}$ & 0 & 6 & 3 & 6 & 2 & 0 & 17 & -4 \\
\hline $\begin{array}{l}\text { 12. There are adequate } \\
\text { opportunities to attend } \\
\text { sports events }\end{array}$ & 0 & 3 & 5 & 3 & 3 & 3 & 17 & -6 \\
\hline $\begin{array}{l}\text { 13. Quality of Health Care } \\
\text { and services covers my } \\
\text { needs }\end{array}$ & 7 & 4 & 0 & 3 & 3 & 0 & 17 & 9 \\
\hline
\end{tabular}




\begin{tabular}{|c|c|c|c|c|c|c|c|c|}
\hline $\begin{array}{l}\text { 14. The quality of Education } \\
\text { services covers my needs }\end{array}$ & 4 & 3 & 2 & 4 & 3 & 1 & 17 & 1 \\
\hline $\begin{array}{l}\text { 15. Land and construction } \\
\text { cost of domestic homes is } \\
\text { praiseworthy }\end{array}$ & 1 & 5 & 2 & 6 & 2 & 1 & 17 & -3 \\
\hline $\begin{array}{l}\text { 16. The cost of living is } \\
\text { satisfactory }\end{array}$ & 0 & 1 & 3 & 10 & 2 & 1 & 17 & -13 \\
\hline $\begin{array}{l}\text { 17. Quality of life (short } \\
\text { daily distances, low noise, } \\
\text { clean air) is satisfactory }\end{array}$ & 9 & 7 & 0 & 0 & 0 & 1 & 17 & 23 \\
\hline $\begin{array}{l}\text { 18. The quality of Nature is } \\
\text { satisfactory }\end{array}$ & 13 & 3 & 0 & 1 & 0 & 0 & 17 & 28 \\
\hline $\begin{array}{l}\text { 19. The quality of the built } \\
\text { environment is satisfactory }\end{array}$ & 5 & 8 & 4 & 0 & 0 & 0 & 17 & 18 \\
\hline $\begin{array}{l}\text { 20. The local Public } \\
\text { Administration is effective }\end{array}$ & 2 & 5 & 3 & 4 & 1 & 2 & 17 & 7 \\
\hline $\begin{array}{l}\text { 21. Degree of involvement } \\
\text { of citizens in decision } \\
\text { making process is sufficient }\end{array}$ & 4 & 8 & 2 & 1 & 1 & 1 & 17 & 13 \\
\hline $\begin{array}{l}\text { 22. I generally feel security } \\
\text { (from criminal activities) }\end{array}$ & 10 & 3 & 3 & 0 & 1 & 0 & 17 & 21 \\
\hline $\begin{array}{l}23 . \quad \text { I trust the local } \\
\text { authorities (municipality) }\end{array}$ & 6 & 8 & 2 & 1 & 0 & 0 & 17 & 19 \\
\hline $\begin{array}{l}\text { 24. Generally the locals are } \\
\text { trustworthy }\end{array}$ & 6 & 7 & 4 & 0 & 0 & 0 & 17 & 19 \\
\hline $\begin{array}{l}25 . \text { My interest for the local } \\
\text { politics is high }\end{array}$ & 2 & 1 & 6 & 7 & 1 & 0 & 17 & -4 \\
\hline
\end{tabular}

\section{Government Stakeholder Responses}

The above opinions from resident and business respondents tend to complement and match fairly well the opinions expressed by one of the co-authors of this article (CP). Such opinions were being expressed in relation to two survey questionnaires crafted so as to be complimentary to the previous two, soliciting opinions about Kökar's attractiveness to: (a) residents; and (b) economic activities.

The top priority for attracting (and keeping) residents is claimed to be the availability of jobs: presumably, not just seasonal jobs in summer (around the tourist industry) but also allthe-year-round jobs. This reason is followed by networks of trust and of rich social capital, quality of transport services, quality of life (short daily commutes, low noise, clean air) and the beauty/quality of nature. These variables are seen to be the main magnets for luring people to Kökar, and keeping them there. These four policy areas are seen to be the most important ones to be addressed. 
When it comes to the attraction of businesses, the top priority is felt to be the need to provide trained and qualified human resources. With a population of 262 - of whom just 158 are of working age - it will be a major challenge for any potential business to source labour market needs from the Kökar labour pool. There is simply no way that employees can shuttle to/from work from anywhere else with any regularity: the ferry trip to/from mainland Åland takes almost 2.5 hours each way. Any recruits to businesses who are not from, or already on, Kökar will simply have to relocate there. The commune website reports that "there is room for a painter, hairdresser, masseur, bakers, vegetable growers, fishermen [sic], auto mechanic" but only as self-employed (www.kokar.aland.fi/jobba.html).

\section{Discussion}

\section{What is happening to the Kökar Archipelago?}

Overall, Kökar is maintaining an almost balanced exchange of human resources. Inmigration is almost as high as out-migration, and births are only just trailing behind deaths. Moreover, only 5 out of the 150 economically active are reported as unemployed: people keep busy and earn a living by exploiting the short but busy tourist, second home and pleasure craft season, and engaging in other activities for the rest of the year. Indeed, there are 254 weekend cottages for about 500 summer residents, so the resident population triples in the busy summer season. There are also some 45,000 tourist visitations annually - one fourth of whom come with their own pleasure craft - almost equally divided between Sweden/Aland and Finland. The Kökar commune is also a major year-round (and the largest) employer - providing community work for 23 employees who in turn provide a basic but decent suite of social services: a library with 8,800 volumes, daycare (20 places), school (with 6 teachers for 31 students from grades 1-9, aged 7 to 15) (www.kokar.aland.fi/skola.html), senior care ${ }^{7}$, a health care clinics with a full-time nurse, and a physician who visits once a month ${ }^{8}$. Private sector economic activities include shipping, a bank branch, and the provision of supplies. Most economic activity is locality based. The Kökar commune web-site mentions that there are some 30 businesses, most of which wholeheartedly practise 'portfolio diversification', providing more than one key activity/service. These businesses include: a hotel-and-restaurant ${ }^{9}$, grocery, supermarket, museum (www.kokarmuseum.fi/), bicycle rental, kayak rental, room rental, campingground $^{10}$, tour guides, and an apple orchard/ farm shop ${ }^{11}$. The 'core' (full-time and parttime) economically active population is around 100 persons (see Table 9); with some 40-50 others added on during the peak summer months, taking care of the needs of thousands of hotel guests, guest-house residents, cottage renters, campers and hikers.

\footnotetext{
${ }^{7}$ A new senior home facility will have 11 rooms and 14-16 places: www.kokar.aland.fi/sommarangen.html.

${ }^{8}$ www.kokar.aland.fi/halsovard.html. A dentist visits Kökar once a year.

9 www.brudhall.com/english.php. Brudhall is also the largest employer on Kökar, with 4 employees (who are also the owners). There is also Havspaviljongen, a restaurant with cottage rentals: www.havspaviljongen.com/ and Klobbars, a hostel with cottages and a restaurant: www.klobbars.fi/.

${ }^{10}$ Sandvik Marina and Campground: www.sandvik.ax/index en.php.

${ }^{11}$ www.kokar.aland.fi/foretag.html. Peder Blomsterlund runs a successful operation with a 1,000-tree apple orchard on Kökar. His products include cider, salsa and chutney.
} 
Table 9 - All-year-round workers on Kökar (full and part-time), 2009.

\begin{tabular}{|l|c|}
\hline $\begin{array}{l}\text { Jobs provided by the Coast Guard } \\
\text { and Government of Aland }\end{array}$ & 13 \\
\hline Construction & 4 \\
\hline Community Work (with Commune) & 23 \\
\hline Seamen/women & 45 \\
\hline Tourist Services & 10 \\
\hline Fishing & 1 \\
\hline Farming & 2 \\
\hline Total & $\mathbf{9 8}$ \\
\hline
\end{tabular}

\section{Why is this happening?}

But the exodus of the young is not likely to be stopped. The school population, currently 31 , is projected to drop to just 20 students in 3-4 years. And, as the population balance tilts increasingly towards the older age groups, deaths will increase further relative to births. As the number of residents drops, the tax base of the municipality drops also, challenging its ability to continue offering basic services; let alone consider expanding them. The informal economy is strong and vibrant - the locals fish and hunt birds and moose; they practise reciprocity and cooperation; while those employed as seamen/women bring back home many useful goods with them from their working trips. Both residents and business persons (who after all, are also residents) are wise in identifying the absence of "training opportunities" on the island as the most serious disadvantage. Can this deficit be remedied? Although so many of the current residents are 'immigrants' to Kökar, there do not appear to be any deep and damaging political splits and divisions within the population and most appear keen on facing the challenges of the livability of their island home.

\section{What to do?}

The island already hosts an 'Artist Residence' facility ${ }^{12}$; one wonders to what extent could a fully-fledged art school develop on the island, connected to its core natural attractions? Perhaps a public-private partnership could be developed into a year-round educational activity. The link with local artistic talent could then help 'brand' the island for the purpose of attracting niche tourism, as well as possible summer 'second homers' or longer-term new residents. There is a 'goodness of fit' between such an activity and the beauty, tranquillity and security of the place, its "Garden of Eden" feel", as well as with its artistic connections ${ }^{14}$. Almost everybody on Kökar has been reported as 'doing music' in some form

12 www.ateljeesaatio.fi/english/ateljeeluettelo.html\#kokar. For a glimpse of how visiting artists have experienced this facility see: www.meganandmurray.com/2008/06/land-archipel-1.html\#. There is actually another facility, on Källskär.

13 As exemplified by the story of Baron Göran Åkerhielm and his connection with the isle of Källskär: http://www.koivurinta.com/kaellskaer.html.

14 Kökar has a vibrant culture. Apart from five resident, landscape-inspired artists (like Satu Kiljunen www.arts.ax/eng/Arts.html) there are various musicians (old and young, folk music, a choir and rock bands). The Skrå band has a short video-clip at: $w w w . y o u t u b e . c o m / w a t c h ? v=t f D b L 0 B n Q 3 A \&$ faeture=related. 
(Karlsson, 2007). The artist-in-residence facility already welcomes some 20 artists a year; and some 20,000 students have visited the facility over the last decade (Kokar Culture, 2009). Such a strategy has been tried elsewhere and it has avoided population declines in other small islands: a good example is Yeu, the only one out of 14 islands on the West coast of France not to have suffered any population decline during the past 130 years (Péron, 2004).

Intimately connected to this idea is the historical relationship of Kökar as place of religious inspiration, spirituality, prayer and pilgrimage. The island has a very long connection to the Franciscan order. A Franciscan monastery, now in ruins, was founded in Hamnö in around 1472 AD. It appears to be the place from where "one of the Western World's first organized measures for providing succour to the shipwrecked was initiated" (Evans 2003: 193). A Franciscan festival is held every summer, in early July, with some 300 to 500 visitors coming from Finland, Sweden and other parts of Europe. This activity forms part of a semireligious, semi-spiritual network of which Kökar is the hub. The event has an ecumenical, ecological and cultural appeal. Of course, islands and pilgrimages go together very nicely: not only in the explicit sense ${ }^{15}$; but also in the way in which so much of tourism is conceived as a pilgrimage or retreat of sorts.

The feasibility of developing more local, natural products should also be explored. The apple orchard and its output is one excellent idea of locally sourced and processed 'gourmet' products that are likely to appeal to visitors interested in the experience economy - much like the Ålvados from the Tjudö Vineyard on mainland Åland, which also has apples as its basic ingredient (Visit Åland, 2010). These products/souvenirs are not price sensitive, can contribute to considerable local added value, and can be branded in consolidation with the island's own image (e.g. Baldacchino, 2005). Moreover, they can be easily combined with site visits, sampling sessions, and other events that combine production with consumption and a more memorable, $360^{\circ}$ experience ${ }^{16}$.

There are considerable synergies to be explored between art, religion and local food in an isolated environment. Kökar could further develop itself as a site for 'pilgrimages' (today, we call them retreats, or team building exercises) by company managers and other groups, sampling local wholesome produce, and indulging in art therapy or art creativity exercises. This is a tourism niche which can appeal to relatively more affluent visitors. Better connectivities to mainland Åland as well as other locations would help make such an experience more accessible to such potential clients of the Kökar experience.

From an environmental perspective, a recent assessment reveals that the overall status of the Baltic Sea remains "unacceptable" and "in bad shape", although there are some encouraging signs of improvement. Excessive pollution loads of nitrogen and phosphorus from the catchment area to the Baltic are still driving overgrowth of algae and plants in most of the Baltic Sea. This phenomenon - also known as eutrophication - is prevalent in all parts of the Baltic Sea except for certain places in the Gulf of Bothnia and the Kattegat. But there is also

\footnotetext{
${ }^{15}$ Islands like Lindisfarne (England), Iona (Scotland) and Skellig Michael (Ireland) are world renowned as sites of pilgrimage, and attract considerable niche tourism today (e.g. Timothy \& Olsen, 2006).

${ }^{16}$ Peder Blomsterlund has done well, not just in processing his apples but also in luring thousands of visitors to his farm: over 5,000 customers/tourists in summer 2009.
} 
a decreasing trend in the pollution loads, and at least part of this decrease is probably an outcome of management measures taken by Baltic Sea countries (Baltic Marine Environment Protection Commission, 2009).

The Åland Government has not been idle. There is a special committee of cabinet that includes 6 Ministers plus a representative of each of the 6 archipelago municipalities. In February 2009, they launched a series of workshops to critically discuss four possible future scenarios for the archipelago: slowly forward; full steam ahead; 'disneyland' and backwater. For each of these, a series of measures was considered, including a different transport infrastructure whose rationale departs from the thinking of the 1970s, when the current fleet of sea ferries (large and slow) was conceived (Ålands Skärgårdsnämnd, 2009). Faster catamarans, for example, linking the archipelago at least to mainland Åland, but possibly also to South-west Finland, could make life on Kökar much more bearable, especially for potential new settlers.

As far as transport to and from the mainland is concerned, the four key issues to be considered in island connectivity are: choice, frequency, time and price (CPMR, 2002: especially 25-28). For Kökar, there is very limited choice: the ferry is the only means of public transportation to Alland; the only other option is a (longer) ferry trip to Korpo. Frequency is limited, since there are only from three to five ferry trips per day, depending on the season ${ }^{17}$. Time can also be improved: the current 2.5-hour journey each way can be cut shorter with faster vessels. The only consolation is price which, for the Kökar residents, is the most advantageous possible, since it is free. One therefore wonders whether there is scope for at least a seasonal service by helicopter or seaplane from Mariehamn direct to Kökar and back $^{18}$. A 150-minute journey either way, with a choice of very few departure times - and this, just to get to Långnäs - can be challenging, and especially so when and if time is at a premium (as in a health emergency or business deal). Any such service could also operate as a sight-seeing operation. A helicopter or seaplane service would of course require no paved runway. A service could also be considered to/from Korppoo or Åbo/Turku.

Internet connectivity is also being improved. An underwater cable should make broadband available to the islanders once this is completed - with high access speeds of $2 \mathrm{MB} / \mathrm{second}$. Currently, internet surfers have to make do with ADSL connections (typically $256 \mathrm{~KB} / \mathrm{sec}$ ) or connect via GSM-enabled mobile phones and devices.

Finally, so much depends and revolves on the ability to maintain or even grow the resident population. Some of the young people of Kökar - once they leave to go to college, university or to secure employment - could come back, often married and with children. There are jobs available on Kökar, but these have to do with maintaining the community, or servicing the hospitality sector and the 'experience economy'. If not employed by the municipality, these jobs invariably depend on self-employment, hard work and initiative. A broadband connection to the world-wide-web could also encourage new residents and new entrepreneurs whose work is not dependent on being physically in a specific place.

\footnotetext{
17 There are 24 trips per week during winter; 27 trips per week in spring and autumn, and 32 trips per week in summer. See Alandstrafiken (2010), especially page 10.

${ }^{18}$ A helicopter can already be called in to airlift patients in emergencies, but only when the weather permits.
} 


\section{Conclusion}

The key magnets to attracting and maintaining a population on Kökar are also likely to depend on the ability of the island to maintain its major 'appeal': peace and quiet, security, the art scene, all surrounded by an almost spiritual natural beauty and tranquility - while at the same strategically improving its links with mainland Aland and the rest of the world. A 'Coney Island' scenario - where Kökar becomes a magnet for thousands more tourists and possible cruise visitors - may appear attractive, but this would only hasten the demise of the community and its cherished way of life, succumbing to Disneyfication. There is a growing segment of the urban population that is tired of stressful city life, daily commuting to get to work, pollution, crime, consumerism ... these "urban refugees" - like architects Jens Karmert and Marina Karlman and their two children (Ålandstidningen, 2009) - could be tempted to settle on a place like Kökar, restoring its empty old houses for resettlement. But, realistically, these individuals would also wish to have a connection to the metropole - for shopping, opera, higher education, art galleries. They would like to have the best of both worlds. Kökar today cannot offer this. But it could, with some intelligent long-term plans for its transportation infrastructure. The advantage of Kökar, and of Åland generally, is that it is not a peripheral backwater in the middle of nowhere - but, rather, bang in the middle of the narrowest part of the Baltic Sea, in between the two major and bustling urban hubs of Stockholm and Åbo/Turku. The situation, thus, is far from hopeless.

European islands are well placed to exploit national and regional funding; but not so much with a view to provide and guarantee a regular flow of financial assistance from the metropole; this would inculcate a culture of dependency that would be difficult to break out of. However, were the overall accessibility of the metropole to islanders to be improved, along with their appeal, when and if the latter seek and desire it, the attractiveness of islands may bolster the survival prospects of their resident communities well into the 21 st century.

\section{Acknowledgements}

We acknowledge the research leadership in EUROISLANDS to Giannis Spilanis (University of the Aegean, Greece), and we are grateful for the collegial support of Rosemarie Azzopardi (University of Malta) and Mikkel Toudal and Dimitri Ioannides (Centre for Regional and Tourism Research, Bornholm, Denmark). Unless otherwise stated, most of the data reported in this case study is to be credited to ÅUB, the Alland Statistical Bureau, as well as to Christian Pleijel, co-author of this paper, and to Kurt Forsman, Mayor of Kökar. The assistance of Bjarne Lindström, Director of ÅSUB, is also gratefully acknowledged.

This article and its contents reflect the personal views of the authors only and should not be attributed to the European Commission, the European Spatial Planning Observatory Network (ESPON), the Government of Åland, the Municipality of Kökar, or any other individual or organization. 


\section{References}

ÅSUB (2007) Aland in Figures, Mariehamn, Åland Islands Statistical Agency.

ÅSUB (2009) Aland in Figures, Mariehamn, Åland Islands Statistical Agency, www.asub.ax/files/lsiff09En.pdf.

Ålands Skärgårdsnämnd (2009) Skärgårdstrafiken 2020: Rapport från ett öppet och kreativt seminarium den 4 februari 2009 om vår framtida skärgårdstrafik [Archipelago Transportation: Report of a Seminar held on February 4 2009].

Ålandstidningen (2009) No. 238, Mariehamn, Åland, October 17.

Ålandstrafiken (2010) Inter-island Ferry Website, www.alandstrafiken.ax/eng/prislistor.htm.

Archipedalo (2009) In Swedish and Finnish, www.ls.aland.fi/.composer/upload/Bilaga_2_Archipedalo.pdf

Baldacchino, G. (2005) 'Successful Small Scale Manufacturing from Small Islands: Comparing Firms benefiting from Local Raw Material Input', Journal of Small Business \& Entrepreneurship, Vol. 18, No. 1, pp. 21-38.

Baltic Marine Environment Protection Commission (2009) March 3, www.helcom.fi/press office/news helcom/en_GB/EUTRO assessment/

Barthon, C. (2007) 'Bridge Impacts on Islands off the Cast of France' in G. Baldacchino (ed.) Bridging Islands: The Impact of Fixed Links, Charlottetown, Canada, Acorn Press, pp. 219-237.

Bertram, G. \& Poirine, B. (2007) 'Island Political Economy' in G. Baldacchino (ed.) $A$ World of Islands: An Island Studies Reader, Malta and Canada, Agenda Academic and Institute of Social Studies, pp. 323-378.

Briguglio, L. (1995) 'Small Island Developing States and their Economic Vulnerabilities', World Development, Vol. 23, No. 9, pp. 1615-1632.

CPMR (2002) Off the Coast of Europe: European Construction and the Problem of the Islands, Rennes, France, Eurisles on the initiative of the Islands Commission, Conference of Peripheral Maritime Regions.

Depraetere, C. (2007) 'Island Locations and Classifications' in G. Baldacchino (ed.) A World of Islands: An Island Studies Reader, Malta and Canada, Agenda Academic and Institute of Social Studies, pp. 75-76.

ESPON (2010) ESPON 2013 Programme, www.espon.eu/main/Menu_Programme/Menu_Mission/index.html.

EUROISLANDS (2010) EUROISLANDS: The Development of the Islands - European Islands and Cohesion Policy, www.espon.eu/main/Menu Projects/Menu TargetedAnalyses/EUROISLANDS.html 
Evans, C. (2003) Rescue at Sea: An International History of Lifesaving, Coastal Rescue Craft \& Organisations, UK, Conway Maritime Press.

Guild Travel (2010) The Archipelago Sea \& Aland Archipelago Cruise, www.guildtravel.com/tourscruises/the-archipelago-sea-aland-archipelago-cruise/.

Hintjens, H.M. (1991) 'France in the Caribbean' in P.K. Sutton (ed.) Europe and the Caribbean. London, Macmillan, pp. 37-70.

Journal of NordRegio (2006) 'Aland', special issue dedicated to insular employment, Vol. 6(1), pp. 14-15.

Karlsson, M. (2007) 'Vad behövs i musiklivet?' [What is needed in the music scene?], Finland, Åbo Akademi: http://web.abo.fi/meddelanden/forskning/2007_13 musik.sht

Kökar Commune (2009) Kokar Commune Web-site, www.kokar.aland.fi/.

Kökar Kultur (2009) Artist Residences in the Finnish Archipelago, www.kokarkultur.com/.

Lindström, B. (1997) 'Åland's Challenge to the Baltic Sea Region: Are Territorial Sovereignty and a Common Public Discourse Preconditions for a Functioning Democracy?' In P. Joenniemi (ed.) Neo-Nationalism or Regionality: The Restructuring of Political Space around the Baltic Rim. Report 1997/5. Stockholm and Copenhagen, NordRefo, pp. 235-252.

Lindström, B. (2000) 'Culture and Economic Development in the Åland Islands' in G. Baldacchino and D. Milne (eds.) Lessons from the Political Economy of Small Islands: The Resourcefulness of Jurisdiction, New York: St Martin's Press, in association with Institute of Island Studies, University of Prince Edward Island, pp. 107-21.

Lindström, B. (2009) Towards the Third Generation of Regional Policy: Lessons from the Nordic Autonomies and Peripheral Regions. Mariehamn, Åland Islands Statistical Agency (ÅSUB), Report 2009: 2, www.asub.ax/files/Rapport2009.2.pdf

Moncada, S., Camilleri, M., Formosa, S. \& Galea, R. (2010) 'From Incremental to Comprehensive: Towards Island-Friendly European Union Policymaking', Island Studies Journal, Vol. 5, No. 1, pp. 61-88.

Per (2008) Blog Entry from Per, from Finland. Blog site at: www.tripsay.com/destination/K\%C3\%B6kar.

Péron, F. (2004) 'The Contemporary Lure of the Island', Tijdschrift voor Economische en Sociale Geografie, Vol. 95, No. 3, pp. 326-339.

Planetware (2009) www.planetware.com/aland-islands/kokar-sf-ahv-kok.htm

Royle, S.A. (2007) 'Islands off the Irish Coast and the 'Bridging Effect' in G. Baldacchino (ed.) Bridging Islands: The Impact of Fixed Links, Charlottetown, Canada, Acorn Press, pp. 203-218. 
Skårgårdscentrum Korpoström (2006) Anchorage, publication supported by the European Union and the State Provincial Office of South-West Finland.

Skärgårdssmak (2009) 'Welcome to Skärgårdssmak: A Flavour of the Archipelago', www.skargardssmak.com/start.con?iLan=3.

Srinivasan, T. N. (1986) 'The Costs and Benefits of Being a Small, Remote, Island, Landlocked, or Ministate Economy', World Bank Research Observer, Vol. 1, No. 2, pp. 205218.

Timothy, D.J. \& Olsen, D.H. (eds.) (2006) Tourism, Religion and Spiritual Journeys, London, Routledge.

Visit Åland (2010) Tjudö Vineyard, Åland Official Tourist Gateway, www.visitaland.com/tjudovingard/en. 